\title{
HYDRO-METEOROLOGICAL ASPECTS OF THE 2021 SOUTH KALIMANTAN FLOOD: TOPOGRAPHY, TIDES, AND PRECIPITATION
}

\author{
Munawir B. Pratama1*, Rafida M. Withono², Ismail N. Azkiarizqi2 \\ 10 cean Engineering Department, Institut Teknologi Bandung \\ ${ }^{2}$ Water Resources Engineering and Management Department, Institut Teknologi Bandung \\ *e-mail: munawirbintang@gmail.com \\ Received: 01 March 2021; Revised: 26 March 2021; Accepted: 01 July 2021
}

\begin{abstract}
The 2021 South Kalimantan flood was recorded as the most serious ever to have taken place in the province. It occurred due to high-intensity rain during the period 10-19 January, accompanied by a spring tide. This study provides an overview of the disaster, with reference to the hydrometeorological conditions (topography, tides, and precipitation). The method used was the analysis of the precipitation and its monthly rainfall pattern anomalies using remote sensing data. A Digital Elevation Model (DEM) was also analyzed to indicate the most noticeably flood-affected area. In certain areas, total precipitation during the ten days reached $672.8 \mathrm{~mm}$, with daily precipitation peaking at 255 $\mathrm{mm}$ on January 14 , greater than the 25 -year return period value. The flood coincided with a spring tide, which peaked at $1.21 \mathrm{~m}$ on the evening of January 15. Using 20-year GPM data, it was found that ENSO and IOD coexisted with both the highest and lowest anomalies. With a La Niña event at the end of 2020, a positive precipitation anomaly in 2021 was expected. The extreme precipitation is suspected to be the main driver of the 2021 South Kalimantan flood, whose impact was worsened by the spring tides. This study conducts further research on the correlation between land-use change, rainfall, spring tide and flooding in South Kalimantan. In addition, it is recommended that the government plan flood risk management by prioritizing areas based on vulnerability to climate hazards.
\end{abstract}

Keywords: Natural Disaster, Hydrological Hazard, Meteorological Hazard, Indonesia, Extreme Events, Precipitation Anomaly.

\section{INTRODUCTION}

Natural disasters are categorized into six groups: geophysical, hydrological, meteorological, climatological, biological, and extraterrestrial (IRDR, 2014). Since early 2020, a biological hazard, namely Covid19 , has hit and kept busy the Indonesian government and those of countries across the globe. In addition, geophysical, hydrological, and meteorological disasters occurred in various regions in Indonesia over a short period of time in early 2021.

In South Kalimantan Province, extreme rainfall took place for several days, resulting in flooding. These were not the first floods in the region; there is documentation of flooding in 1928 in
Barabai, Hulu Sungai Selatan Regency (KITLV, 1928). The Central Bureau of Statistics (Badan Pusat Statistik - BPS) of South Kalimantan also recorded 286 flood events from 2012 to 2019. Banjarmasin was the least affected location, with only one incident.

Balangan Regency had 78 incidences of flooding (BPS Kalimantan Selatan 2021). However, the floods that hit South Kalimantan in January 2021 were said to be more intense than in previous events. As of January 14, BNPB reported that 24,379 houses had been inundated, and 39,549 people evacuated (BNPB, 2021a).

Studies on hydro-meteorological disasters in Indonesia have been conducted by several researchers, with 
analysis from the perspectives of hydrology, meteorology, urban, and climate change (Putra, Putro, \& Hadi, 2016; Latief, Putri, \& Hanifah, 2018; Dwirahmadi, Rutherford, \& Phung, 2018; Takagi, Esteban, \& Mikami, 2016). Putra et al. (2016) developed flood hazard mapping for Jakarta (the capital city of Indonesia) using HEC-HMS and ANUGA. Their model was based on rainfall, soil type, land use, and land elevation. In addition, Takagi et al. (2016) assessed the impact of tides, land subsidence, and sea-level rises on flood hazards on the North Jakarta coast, utilizing topographical data and recorded abnormal high tides. However, this kind of advanced study mainly focuses on the cases of Jakarta or other big cities.

However, there has been little research on the hydro-meteorological disaster in Kalimantan, especially in the South Kalimantan Area. To move to the advanced stage of study in this field, and to have an impact on decision making, preliminary research is required to highlight the natural characteristics of the study area, and to attract the interest of other researchers.

The objective of this study is to establish the drivers of the 2021 South Kalimantan flood. Natural conditions such as topography, precipitation, and tides are studied; the importance of such basic data has been demonstrated in conducting impactful research (Putra et al., 2016; Takagi et al., 2016; Hurford, Maksimovic, \& Leitao, 2010). In this study, these data will be described individually, and their interrelations with the flood events will be scrutinized. The findings are expected to aid readers and future researchers in understanding the phenomenon in question.

\section{MATERIALS AND METHODS}

A brief summary of the materials and methodology is given in Figure 2-1. Data such as flood events/records, topography, tidal elevation, and precipitation (both of the observation and prediction data) were gathered. The precipitation data were extensively analyzed, with a Signal Detection Theory test conducted to determine which prediction gave the best representation.

Furthermore, one precipitation prediction was selected and used to determine the extreme values in some return periods using a 20-year dataset. Additionally, yearly variability was studied for understanding the flood event using the long-term time-series data. Based on the topography, tides, observed rain, flood events, extreme precipitation values, and precipitation anomalies, a discussion on hoped the flood mechanisms would be provided.

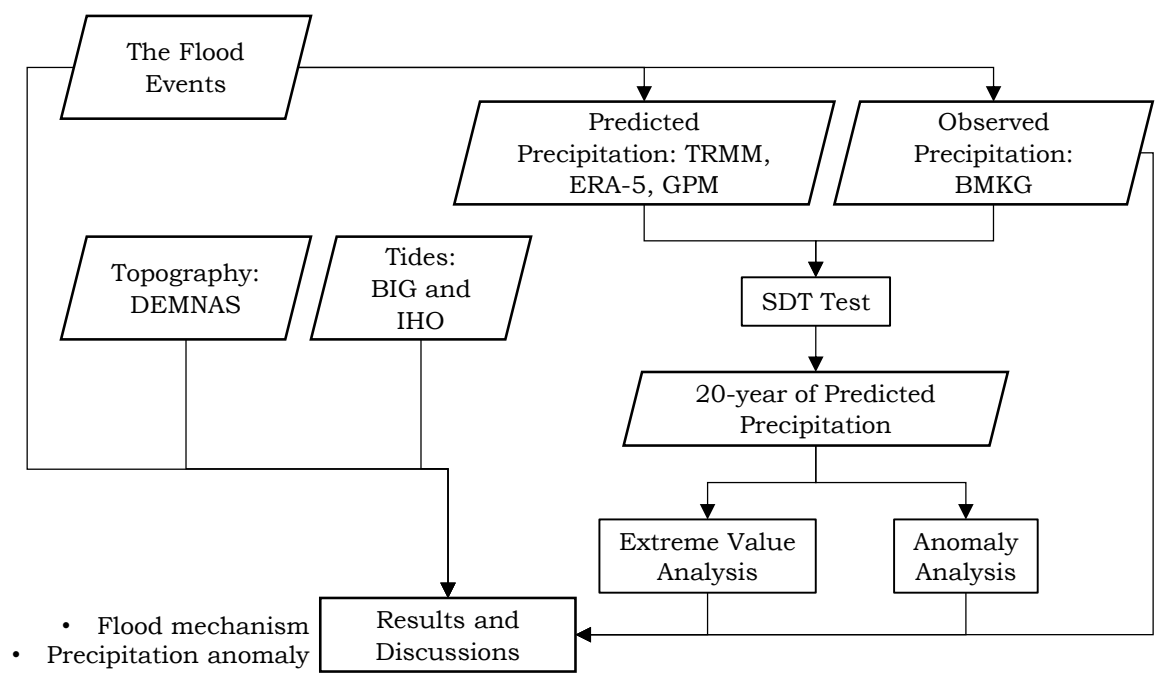

Figure 2-1 Flow chart diagram summarizing the materials and research Methodology. SDT stands for Signal Detection Theory 


\subsection{Area of Study}

The study focuses on the 2021

South Kalimantan flood. The study area is shown in Figure 2-2, which includes 13 cities, with details provided in Table 2-1. The total population of South Kalimantan in 2019 was 4.24 million, spread across an area of $38,744.23 \mathrm{~km}^{2}$ (BPS Kalimantan Selatan, 2021). However, $22.36 \%$ of the population was concentrated in the cities of Banjarmasin and Banjarbaru, which only occupy $1.5 \%$ of the area of the province.

According to the literature (BPS Kalimantan Selatan, 2021), 30.16\% of the land in South Kalimantan comprises forest and shrubs, with $20.09 \%, 10.98 \%$, $2.33 \%$, and $1.44 \%$ respectively dedicated to plantations, rice fields, settlements, and mining. Geographically, the average height above sea-level of the province is $17 \mathrm{~m}$, with 38,809 hectares of rivers, lakes, reservoirs, and ponds. The Barito River is the largest river in South Kalimantan and the widest in Indonesia.

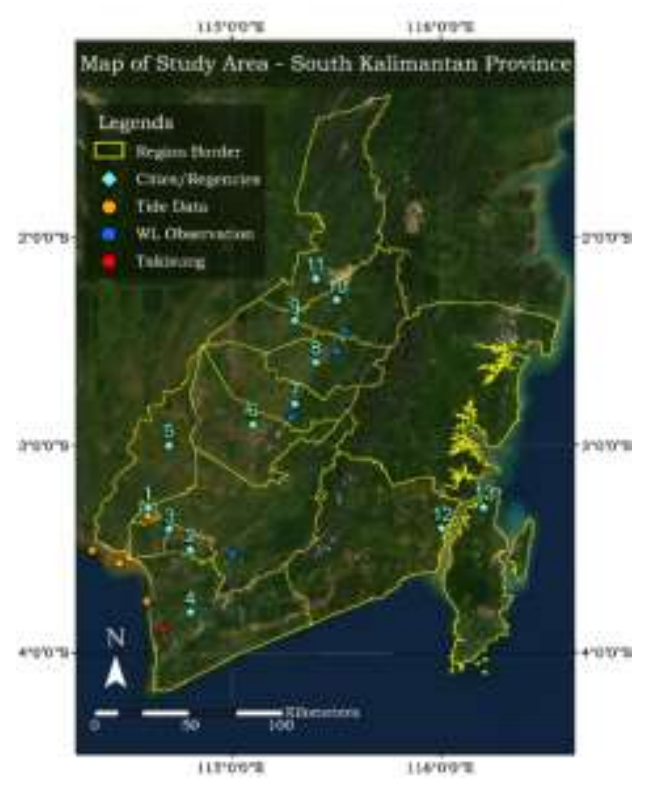

Figure 2-2 Overview of South Kalimantan

Province. The area of interest is cities $1-11$

\subsection{Flood Records}

A schematization of the Barito River in South Kalimantan Province is illustrated in Figure 2-3 (Manalu, 2021). The eleven flooded cities are visualized in in the figure. In addition, a general summary of the flood events is shown in Table 2-2. These data were compiled from field observations and disaster reports provided by BPBD. From January 10 2021, five cities were affected by the flooding. The water levels at the four weirs (upstream) on January 10-13 were 100, 26, 42, and $25 \mathrm{~cm}$ in Banjar (Karang Intan), Balangan (Pitap), HSS (Amandit), and HST (Batang Alai), respectively.

Table 2-1: List of cities, main districts, and elevation (BPS Kalimantan Selatan, 2021)

\begin{tabular}{cllc}
\hline No & City & $\begin{array}{l}\text { Main } \\
\text { District }\end{array}$ & $\begin{array}{c}\text { Elevationa } \\
(\mathbf{m})\end{array}$ \\
\hline 1 & Banjarmasin & - & 5 \\
2 & Banjarbaru & - & 27 \\
3 & Banjar & Martapura & 13 \\
4 & Tanah Laut & Pelaihari & 64 \\
5 & Barito Kuala & Marabahan & 9 \\
6 & Tapin & Rantau & 8 \\
7 & HSS* & Kandangan & 11 \\
8 & HST* & Barabai & 9 \\
9 & HSU* & Amuntai & 6 \\
10 & Balangan & Paringin & 29 \\
11 & Tabalong & Tanjung & 16 \\
12 & Tanah & Batulicin & 2 \\
13 & Kotabaru & Kotabaru & 32 \\
\hline
\end{tabular}

a Data in Mean Sea Level (MSL)

* HSS: Hulu Sungai Selatan

* HST: Hulu Sungai Tengah

* HSU: Hulu Sungai Utara

After the heavy rains of January 14-15, the observations at the weirs rose to $230,202,150$, and $260 \mathrm{~cm}$ in each location. Subsequently, the floods hit eight cities with a considerable level of inundation on January 14 . The most severe impacts were felt in Banjar (Pengaron), Tanah Laut (Bumi Makmur), Tapin (Binuang), and HST (Barabai and 


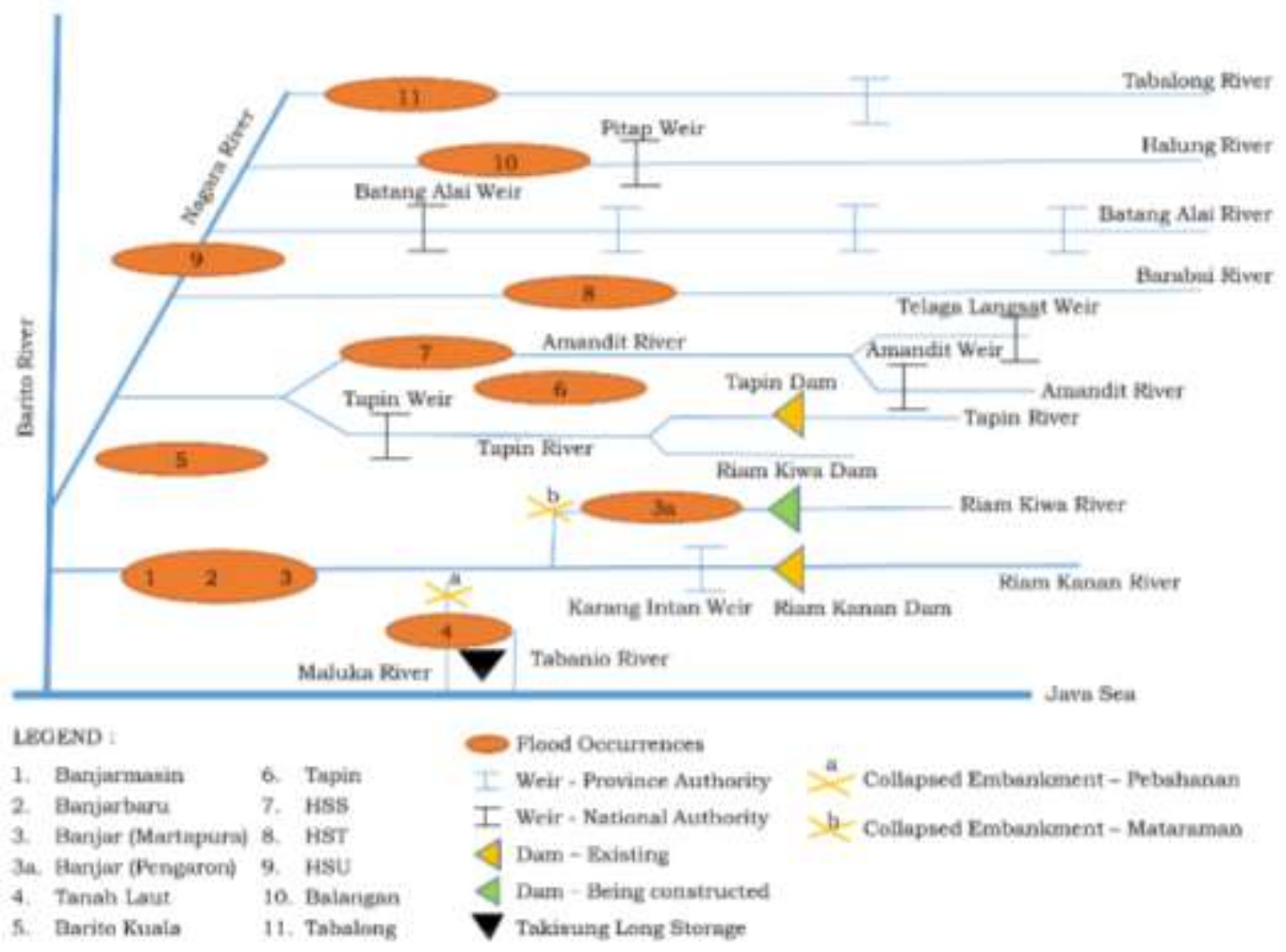

Figure 2-3 Schematization of the Barito River system in South Kalimantan Province.

Hantakan), where water levels rose from around $50 \mathrm{~cm}$ to over $150 \mathrm{~cm}$ overnight (BNPB, 2021b). Banjarmasin, which had not been flooded before, was inundated to a level of $30-50 \mathrm{~cm}$. Tanah Laut, which had been experiencing flooding since January 10, suffered a significant increase in flood height due to a collapsed retaining wall at the Takisung Pond (Balai Hidrologi dan Lingkungan Keairan, 2021).

From January 16-19, the rain lasted for three days with moderate to heavy intensity (BMKG, 2021a). The series of extreme rain events contributed to increasing the discharge of the Barito River to 2.08 billion $\mathrm{m}^{3}$, far exceeding its capacity of 230 million $\mathrm{m}^{3}$ (Tirto, 2021). Table 2-1 shows that 11 cities were flooded on January 16. At the same time, observations at the weirs showed a gradual decline, namely from 69 to 36 $\mathrm{cm}, 110$ to $40 \mathrm{~cm}$, and 22 to $6 \mathrm{~cm}$ for Balangan, HSS, and HST, respectively. However, in Banjar district, the water level fluctuated between 150 and 170 $\mathrm{cm}$.

As of January 19, five districts remained inundated, as shown in Table $2-1$. Based on the visualization of the Sentinel-1 satellite on January 20 (see Figure (2-4), large-scale inundation occurred in the downstream areas of Barito Kuala, Tanah Laut, and Banjar (Copernicus Sentinel, 2021; Purwonegoro, 2021). Flood events were also observed upstream and identified as lower elevation areas, namely in several areas in Barito Kuala to HSU.

\subsection{Data Compilation}

\subsubsection{Topography}

For the topography, or the digital elevation model (DEM), DEMNAS data were used, which are publicly available. DEMNAS are topographical data with a resolution of $8.3 \times 8.3 \mathrm{~m}^{2}$ for the Indonesian regional area, provided by the Geospatial Information Agency - Badan Informasi Geospasial, BIG (BIG, 2021a). The data are an integration of IFSAR, 


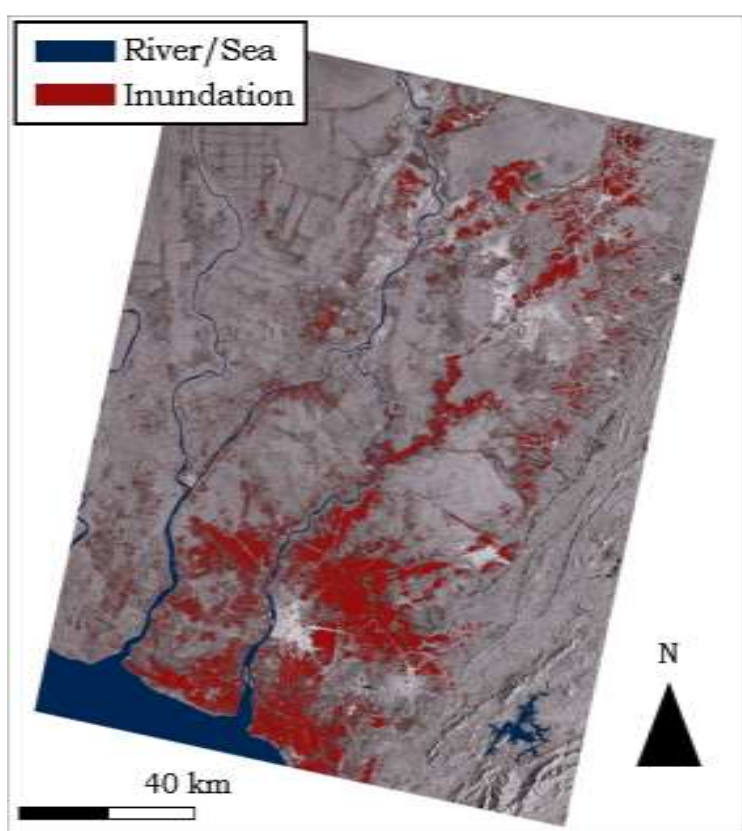

Figure 2-4 Satellite imagery of the inundated area on January 20. Red, blue, and grey represent the inundated area, water bodies, and dry area respectively. Note: Raw data were downloaded from

Copernicus Sentinel (2021) and processed by Purwonegoro (2021) using Multi-Temporal SAR thresholding. Reprinted with permission.

Table 2-2: $\quad$ Records of flood level in centimeters in the 2021 South Kalimantan flood; numbers 111 represent the cities, as shown in Figure 2-2

\begin{tabular}{|c|c|c|c|c|c|c|c|c|c|c|c|c|}
\hline Date & Times & 1 & 2 & 3 & 4 & 5 & 6 & 7 & 8 & 9 & 10 & 11 \\
\hline \multirow{3}{*}{$10 / 01$} & 07:00 & - & $20-$ & - & \multirow{5}{*}{$\begin{array}{c}20- \\
40\end{array}$} & - & - & - & - & - & - & \multirow{4}{*}{$<50$} \\
\hline & $14: 00$ & - & 40 & - & & - & - & - & - & - & - & \\
\hline & $22: 00$ & - & $\begin{array}{c}30- \\
70\end{array}$ & 30 & & - & - & - & - & - & - & \\
\hline \multirow{3}{*}{$11 / 01$} & 07:00 & - & \multirow{3}{*}{$\begin{array}{c}30- \\
40\end{array}$} & 40 & & - & - & \multirow{7}{*}{$\begin{array}{c}20- \\
40\end{array}$} & - & - & - & \\
\hline & $14: 00$ & - & & \multirow{3}{*}{20} & & - & \multirow{2}{*}{-} & & - & - & - & - \\
\hline & $22: 00$ & - & & & \multirow{4}{*}{$\begin{array}{c}40- \\
50\end{array}$} & - & & & - & - & - & - \\
\hline \multirow{3}{*}{$12 / 01$} & 07:00 & - & \multirow{4}{*}{$<30$} & & & - & \multirow{6}{*}{$\begin{array}{c}20- \\
40\end{array}$} & & - & - & - & - \\
\hline & $14: 00$ & - & & 30 & & - & & & - & - & - & - \\
\hline & $22: 00$ & - & & \multirow{4}{*}{20} & & - & & & - & - & - & - \\
\hline \multirow{3}{*}{$13 / 01$} & 07:00 & - & & & \multirow{3}{*}{$\begin{array}{c}50- \\
70\end{array}$} & - & & & - & - & - & - \\
\hline & $14: 00$ & - & \multirow{6}{*}{$<50$} & & & - & & \multirow{3}{*}{20} & & - & - & - \\
\hline & $22: 00$ & - & & & & - & & & 20 & - & $\begin{array}{c}20- \\
30 \\
\end{array}$ & - \\
\hline \multirow{3}{*}{$14 / 01$} & 07:00 & \multirow{3}{*}{$\begin{array}{c}30- \\
50\end{array}$} & & \multirow{8}{*}{$\begin{array}{c}50- \\
60 \\
(250)\end{array}$} & \multirow{3}{*}{$200^{b}$} & - & \multirow{6}{*}{$\begin{array}{l}50- \\
150^{c}\end{array}$} & & $\begin{array}{l}50- \\
100\end{array}$ & - & \multirow{3}{*}{$\begin{array}{l}70- \\
100\end{array}$} & - \\
\hline & $14: 00$ & & & & & - & & 10 & $100-$ & - & & - \\
\hline & $22: 00$ & & & & & - & & - & 200 & \multirow{4}{*}{50} & & - \\
\hline \multirow{3}{*}{$15 / 01$} & 07:00 & \multirow{3}{*}{$\begin{array}{c}50- \\
60\end{array}$} & & & \multirow{5}{*}{$\begin{array}{c}< \\
100\end{array}$} & - & & \multirow{5}{*}{60} & $100-$ & & & - \\
\hline & $14: 00$ & & $<20$ & & & - & & & 150 & & $30-$ & - \\
\hline & $22: 00$ & & $<20$ & & & & & & & & 100 & \\
\hline 16101 & 07:00 & $30-$ & -10 & & & $<40$ & $30-$ & & $70-$ & $10-$ & & $50-$ \\
\hline $16 / 01$ & $14: 00$ & 50 & $<10$ & & & & 60 & & 100 & 60 & & 60 \\
\hline
\end{tabular}




\begin{tabular}{|c|c|c|c|c|c|c|c|c|c|c|c|c|}
\hline Date & Times & 1 & 2 & 3 & 4 & 5 & 6 & 7 & 8 & 9 & 10 & 11 \\
\hline & $22: 00$ & & & & & & & & & & \multirow{7}{*}{$\begin{array}{c}30- \\
60\end{array}$} & \\
\hline \multirow{3}{*}{$17 / 01$} & $07: 00$ & & & & \multirow{3}{*}{$<70$} & \multirow{7}{*}{$\begin{array}{c}40- \\
60\end{array}$} & & \multirow{4}{*}{$\begin{array}{c}20- \\
30\end{array}$} & \multirow{2}{*}{$\begin{array}{c}50- \\
70 \\
\end{array}$} & & & \\
\hline & $14: 00$ & & & & & & & & & & & \\
\hline & $22: 00$ & & - & & & & $<30$ & & \multirow{3}{*}{$<50$} & \multirow{5}{*}{$<20$} & & \\
\hline \multirow{3}{*}{$18 / 01$} & 07:00 & & - & 30 - & \multirow{3}{*}{$<30$} & & & & & & & $<40$ \\
\hline & $14: 00$ & & - & 50 & & & & 10 & & & & \\
\hline & $22: 00$ & & - & $\begin{array}{c}20- \\
40\end{array}$ & & & - & - & \multirow[t]{2}{*}{$<20$} & & & \\
\hline \multirow{3}{*}{$19 / 01$} & 07:00 & \multirow{3}{*}{$<40$} & - & \multirow{3}{*}{$\begin{array}{c}10- \\
30\end{array}$} & \multirow{3}{*}{$<10$} & & - & - & & & & - \\
\hline & $14: 00$ & & - & & & $\begin{array}{c}40- \\
50\end{array}$ & - & - & - & - & 20 & - \\
\hline & 22:00 & & - & & & $<70$ & - & - & - & - & 10 & - \\
\hline
\end{tabular}

TERRASAR-X, and ALOS PALSAR. Previous studies had shown that DEMNAS offers better accuracy than SRTM (Nurtyawan \& Fiscarina, 2020). The elevation discrepancy between DEMNAS and the measurement data is generally influenced by land cover.

\subsubsection{Tides}

The tidal observation station of BIG in South Kalimantan was less relevant for the study since its location was out of the area of interest (BIG, 2021c). As an alternative, the tide predictions provided by BIG (BIG, 2021b) and IHO (Deltares, 2021) were used, which are also publicly available. BIG data are nationwide tide elevation predictions available hourly. In addition, IHO data consists of tidal constituents and can be generated into elevations using Delft Dashboard.

\subsubsection{Precipitation}

Precipitation analysis requires consistent and continuous data over a long period, for example, > 10 years. Due to the limitations of the observation data, predicted data such as modelling data or indirect observations (satellite) were needed. However, it was necessary to conduct a comparative analysis between the observed and predicted data to ensure the reliability of the latter (Fatkhuroyan, 2019; Supari \& Setiawan, 2013).

\section{BMKG Monitoring}

BMKG, or Badan Meteorologi, Klimatologi, dan Geofisika, is an Indonesian government agency that focuses on and is responsible for, meteorology, climatology, air quality, and geophysics fields (BMKG, 2021a). One of the instruments it employs is the precipitation monitoring tools, which can be found at meteorological or climatological stations.

There are three publicly available monitoring stations in South Kalimantan, namely Syamsuddin Noor Meteorological Station in Banjarbaru, Banjarbaru Climatological Station in Banjarbaru, and Gusti Syamsir Alam Meteorological Station in Kotabaru. Data for each station can be accessed on the BMKG online portal (BMKG, 2021a). Considering the study domain coverage, data from the first two stations were used.

\section{ERA5-Land Prediction (Model)}

ERA5, or ECMWF Re-Analysis 5, is a global atmospheric model developed by the European Center for Medium-range Weather Forecasts (ECMWF). ERA5_Land has 0.1 arc degree resolution. Hourly precipitation from 1981 to 2020 is available globally for the region. Previous studies have shown that the ERA5-Land model is accurate and reliable (Tarek, Brissette, \& Arsenault, 2020). 


\section{TRMM Prediction (Satellite)}

TRMM is the Tropical Rainfall Measuring Mission, which is a joint collaboration between NASA and the Japanese National Space Development Agency. TRMM covers the $50^{\circ} \mathrm{N}-50^{\circ} \mathrm{S}$ region with a resolution of 0.25 arc degrees, and is available up to sub-daily intervals. TRMM data are publicly available from a user-friendly portal (Acker \& Leptoukh, 2007).

\section{GPM Prediction (Satellite)}

GPM (Global Precipitation

Measurement Mission) is a continuation of TRMM, launched in February 2014, and is a collaboration between NASA and JAXA. Apart from being able to detect moderate and heavy rain, GPM is also capable of detecting light rain and snow. Data are available from 2000 to 2020, with a finer resolution, 0.1 arc degree per 30 minutes, and coverage from $60 \circ \mathrm{N}$ 60S (NCAR, 2017). These data can be accessed via the Giovanni portal at specific points, time frames, and intervals (Acker \& Leptoukh, 2007).

\section{RESULTS}

\subsection{Topography Analysis}

The topography of South

Kalimantan is shown in Figure 3-1, and was obtained from the DEMNAS dataset (BIG, 2021a). In general, it is dominated by low-lying land (elevation $<7 \mathrm{~m}$ ), with a presentation of $40.5 \%$ and $61.8 \%$ low sloping land ( slope equals 0.02) (BPS Kalimantan Selatan, 2021). There is a mountainous area in the middle of South Kalimantan area, with the highest elevation of $1,840 \mathrm{~m}$, surrounded by areas with low elevations, where most residential areas are located.

The flood and evacuation points of the 2021 South Kalimantan flood are given in Figure 3-1, as obtained from Geoportal Kalsel (2021). The flood points were concentrated to the east of the mountainous area and distributed from the north to the south of the province. Balai Hidrologi dan Lembaga Keairan (2021) states that flooding occurred in 10 cities within the Barito River Basin, with inundation ranging from 50 to $347 \mathrm{~cm}$. Detailed visualizations of four cities are given in Figures 6 and 7, namely Banjarmasin, Tanah Laut, Banjar, and HSU.

Figure 3-2 shows the cases of Banjarmasin and Tanah Laut. Banjarmasin is situated around $5 \mathrm{~m}$ above MSL and is surrounded by several rivers, such as the Barito and Riam Kanan. The inundation here was around $50 \mathrm{~cm}$, relatively low compared to other areas. However, flooding occurred in densely populated areas, around the main road and Riam Kanan River. In Tanah Laut District, Bumi Makmur and Kurau Sub-Districts are located at an elevation of -3 to $16 \mathrm{~m}$. This area is traversed by a river, and most of the land use is for rice farms. This area was one of the districts with high flooding. The depth of the flood reached $200 \mathrm{~cm}$ at the rice farms and settlements.

Visualization of the Digital Elevation Model (DEM) and flood points for Banjar and HSU is shown in Figure 3-3. Banjar also suffered serious inundation, with some points, as shown in the image, flooded to around $300 \mathrm{~cm}$. However, this area is higher, located just downstream of the mountainous area. In the figure, several basins are shown at a depth of $57 \mathrm{~m}$. HSU is a lowland area, whose main district, Amuntai, is only $6 \mathrm{~m}$ above MSL, although it is $150 \mathrm{~km}$ from the coast. This area is the confluence of two large rivers originating from Balangan and Tabalong. Many flood points were scattered around the junction of the two rivers, with inundation reaching a depth of $60 \mathrm{~cm}$. 

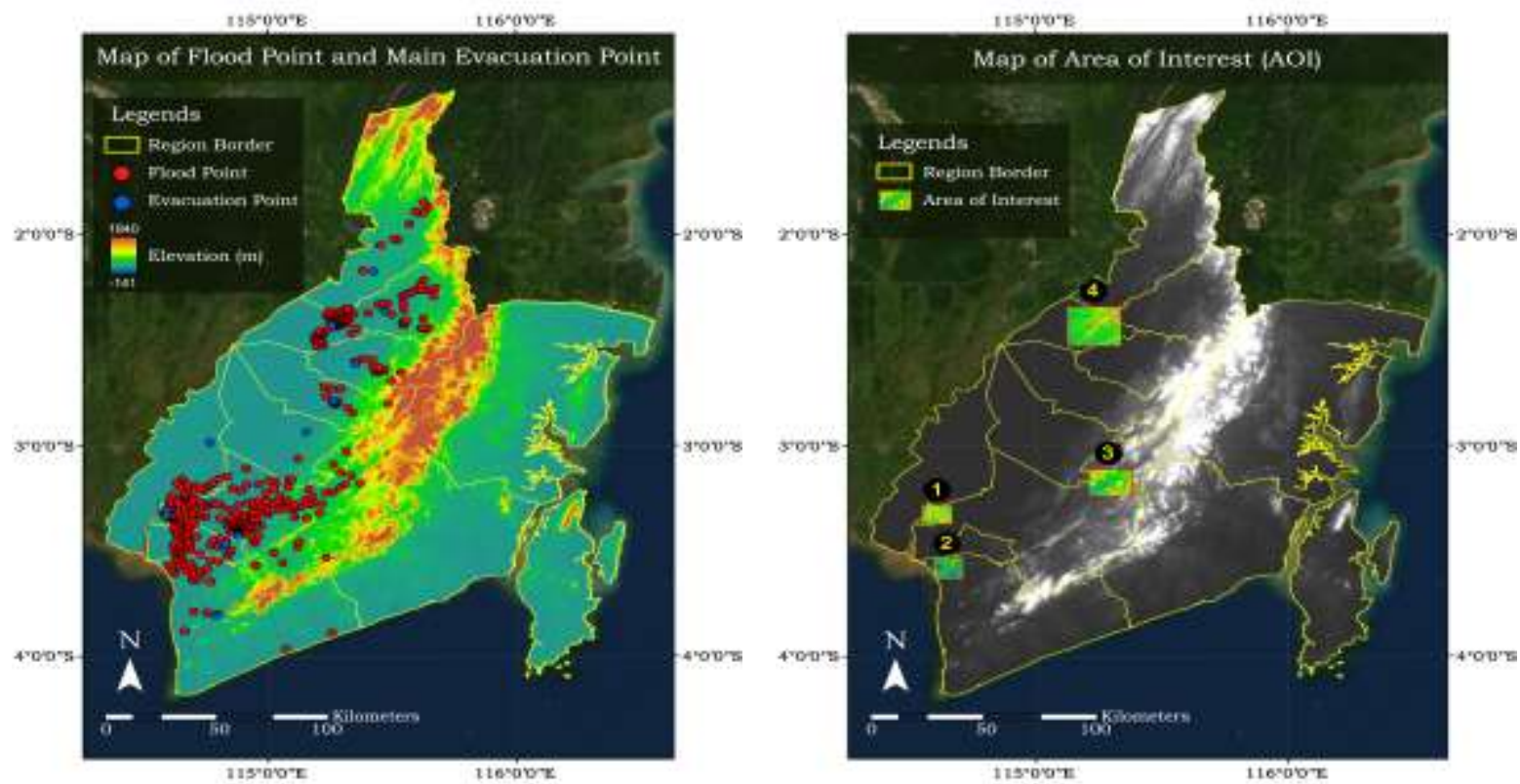

Figure 3-1 (Left) Flood (red dots) and evacuation points (blue dots); and (right) area of interest for the detailed visuals
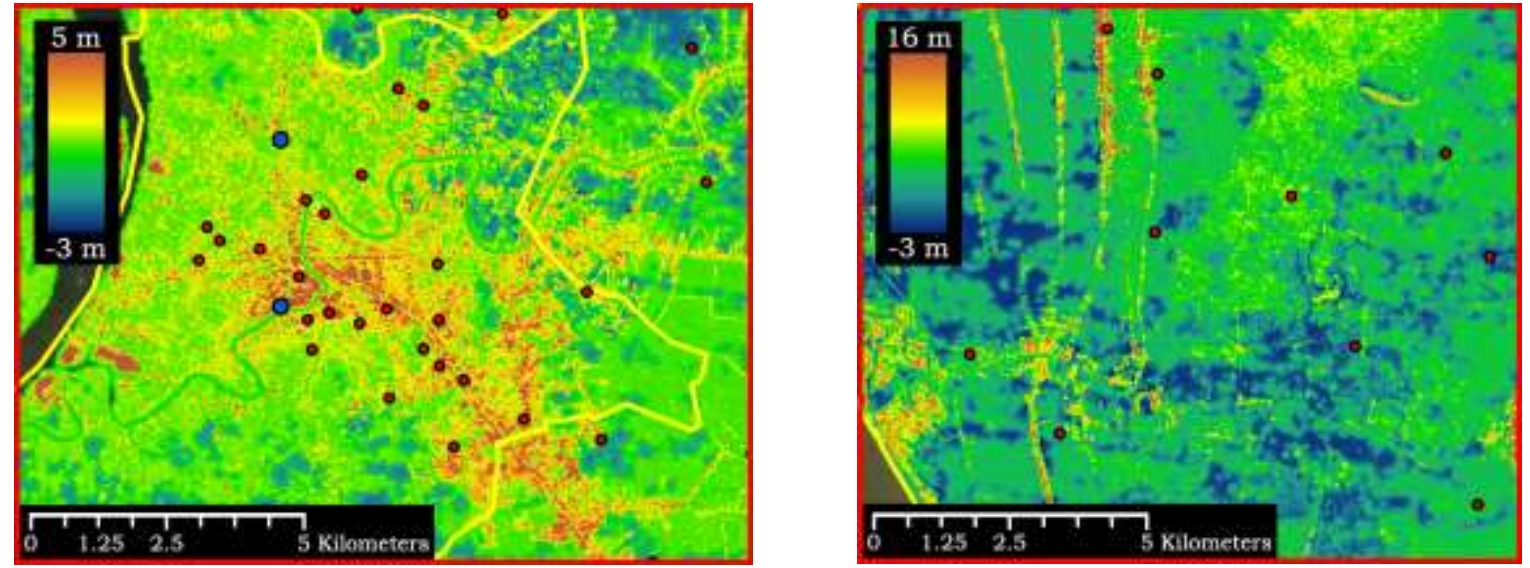

Figure 3-2 DEM (in meter), flood (red dots), and evacuation points (blue dots): (left) Banjarmasin and (right) Tanah Laut
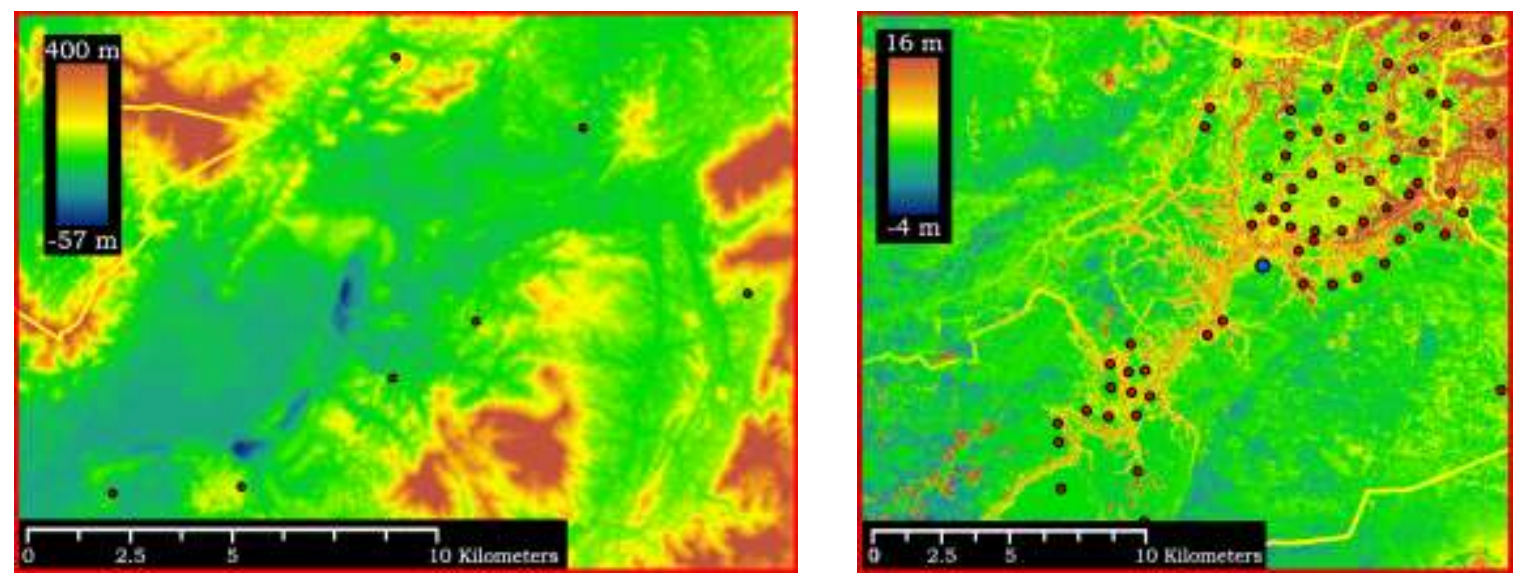

Figure 3-3 DEM (in meter), flood (red dots), and evacuation points (blue dots): (left) Banjar and (right) HSU. 


\subsection{Tide Analysis}

Four points were reviewed using both tidal data alternatives, as shown in Table 3-1. The correlation between the BIG and IHO predictions showed a positive value ( $>$ 0.92); however, BIG could not predict tides in Banjarmasin because it is inland. The IHO data revealed a Formzhal value of $2.50-2.89$, indicating a mixed, mainly diurnal tide (Ko, Jeong, \& Cho, 2018).

Considering the distance from the area of interest and the availability of the tidal constituent, only Banjarmasin and Barito Entrance 1 were used to analyze the flood event. The tide elevation for the last 20 years has been analyzed using ErgElv (open ware for tide least-square analysis), producing a tidal range of 2.73 and $2.93 \mathrm{~m}$ for each point, close to the value of a previous study by JICA (2010). In addition, the Mean High-Water Spring (MHWS) values were 1.09 and $1.04 \mathrm{~m}$, respectively.

Furthermore, the tide in January 2021 was analyzed, with the time series chart given in Figure 3-4. Critical flood conditions began to occur from the night of January 13 and reached their peak on January 15 . The graph in Figure 3-4 shows that a spring tide occurred during the critical flood conditions. The peak elevations on the evening of January 15 reached 1.21 and $1.14 \mathrm{~m}$ in Banjarmasin and Muara Barito, exceeding the MHWS category.

\subsection{Precipitation Analysis}

Precipitation is said to be the main driver of floods and will be analyzed extensively in this research (Balai Hidrologi dan Lingkungan Keairan, 2021). The analysis aims to identify how extreme the precipitation was and to understand the behavior of precipitation anomalies due to global phenomena such as ENSO and IOD.

\subsubsection{Comparison between Observed and Predicted Data}

Signal detection theory (SDT) was used to determine the best data for detecting major rainfall events, especially from the moderate to extreme categories ( $\mathrm{R}>20 \mathrm{~mm} /$ day). The threshold used was the lower limit of heavy rain, which is 50 $\mathrm{mm} /$ day (BMKG, 2021b). SDT was also performed to observe the ability of the prediction data to detect rainy days, with a threshold of $1 \mathrm{~mm} /$ day. SDT defines the value of Hit (A), False Alarm (B), Correct Negative (C), and Miss (D) (Harvey, Hammond, \& Lusk, 1992).

The derived parameters based on the SDT calculations were frequency bias (FBS), probability of detection (POD), false alarm ratio (FAR), critical success index (CSI), and the Heidke skill score (HSS), which were calculated using Equations 31-3-5.

$$
\begin{aligned}
F B S & =\frac{A+B}{A+C} \\
P O D & =\frac{A}{A+C} \\
F A R & =\frac{A}{A+B} \\
C S I & =\frac{A}{A+B+C} \\
H S S & =\frac{2(A \times D-B \times C)}{(A+C)(C+D)(A+B)(B+D)}
\end{aligned}
$$

The calculated values are presented in Table 3-2. Generally, the daily precipitation prediction gave a low coefficient correlation (CC). The table shows that the predicted data tend to overestimate the frequency of rain events (FBS $>1$ ), while the frequency of extreme rain (Table 3-2) tends to be underestimated (FBS $<1$ ). The ability of the data to detect daily rainfall results in a fairly good value, with a POD of $>0.72$. However, they are weak at detecting high precipitation $(\mathrm{POD}<0.31)$. The HSS value was low. 
Table 3-1 Details of tides points

\begin{tabular}{|c|c|c|c|c|c|}
\hline Point & Lat. & Long. & $\mathbf{r} \mathbf{a}$ & Constituent b & Formzhal c \\
\hline Banjarmasin & -3.3333 & 114.6000 & - & $\mathrm{K} 1, \mathrm{O} 1, \mathrm{P} 1, \mathrm{~S} 1, \mathrm{M} 2, \mathrm{~S} 2, \mathrm{~N} 2, \mathrm{~K} 2$ & 2.53 \\
\hline Barito Entrance 1 & -3.5667 & 114.4833 & 0.95 & $\mathrm{~K} 1, \mathrm{O} 1, \mathrm{P} 1, \mathrm{Q} 1, \mathrm{~S} 1, \mathrm{M} 2, \mathrm{~S} 2, \mathrm{~N} 2, \mathrm{~K} 2$ & 2.62 \\
\hline Tabanio & -3.7500 & 114.6000 & 0.99 & $\mathrm{~K} 1, \mathrm{O} 1, \mathrm{P} 1, \mathrm{M} 2, \mathrm{~S} 2$ & 2.89 \\
\hline Barito Entrance 2 & -3.5000 & 114.3333 & 0.92 & $\mathrm{~K} 1, \mathrm{O} 1, \mathrm{P} 1, \mathrm{M} 2, \mathrm{~S} 2, \mathrm{~N} 2, \mathrm{~K} 2$ & 2.50 \\
\hline
\end{tabular}

Table 3-2 SDT statistics for rain events and moderate rain testing

\begin{tabular}{|c|c|c|c|c|c|c|c|c|}
\hline \multirow[b]{2}{*}{ Parameter } & \multicolumn{4}{|c|}{ Rain event; threshold > $1 \mathrm{~mm}$} & \multicolumn{4}{|c|}{ Moderate rain; threshold > $50 \mathrm{~mm}$} \\
\hline & ERA5 & TRMM & GPM & $\begin{array}{c}\text { Corrected } \\
\text { GPM }\end{array}$ & ERA5 & TRMM & GPM & $\begin{array}{c}\text { Corrected } \\
\text { GPM }\end{array}$ \\
\hline $\mathrm{CC}$ & 0.384 & 0.494 & $\underline{0.603}$ & 0.597 & 0.014 & 0.246 & $\underline{0.324}$ & 0.316 \\
\hline FBS & 1.469 & $\underline{1.000}$ & 1.214 & $\underline{0.993}$ & 0.006 & 0.262 & $\underline{0.373}$ & $\underline{0.390}$ \\
\hline POD & $\underline{0.933}$ & 0.729 & 0.860 & 0.771 & 0.000 & 0.197 & $\underline{0.303}$ & $\underline{0.316}$ \\
\hline FAR & 0.365 & $\underline{0.270}$ & 0.291 & $\underline{0.224}$ & $\underline{0.006}$ & 0.247 & 0.190 & 0.190 \\
\hline CSI & 0.607 & 0.574 & $\underline{0.636}$ & 0.631 & 0.000 & 0.185 & $\underline{0.283}$ & $\underline{0.294}$ \\
\hline HSS & 0.321 & 0.459 & 0.458 & $\underline{0.550}$ & -0.012 & 0.210 & $\underline{0.338}$ & 0.348 \\
\hline
\end{tabular}

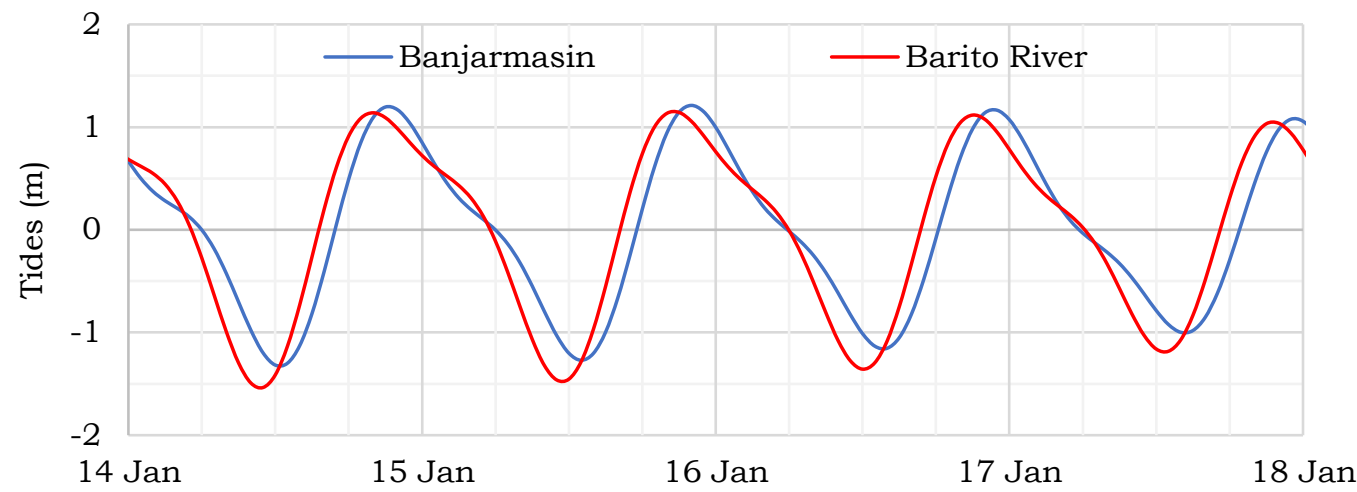

Figure 3-4 Tides around the critical flood time.
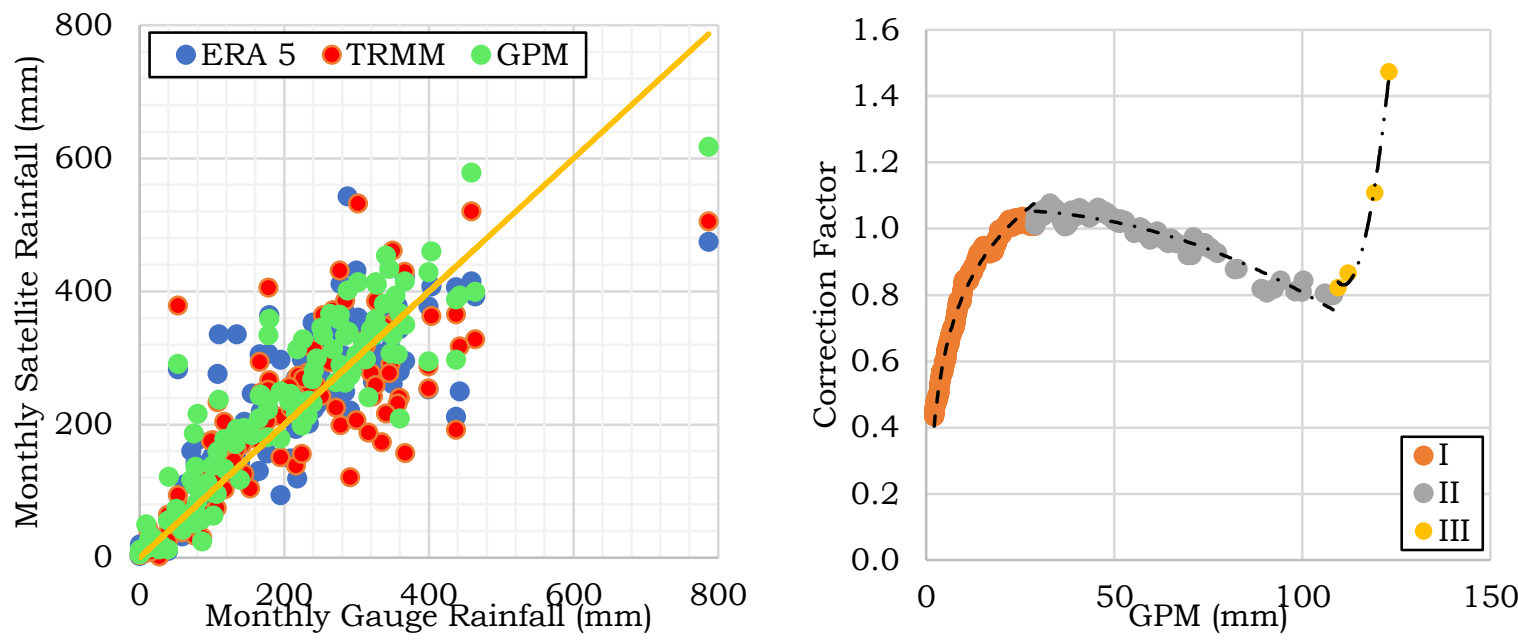

Figure 3-5 (Left) Scatter diagram of the comparison between the observed data and ERA5, TRMM, and GPM data, and (right) range of correction factor application 
Table 3-3 Return periods ( $\mathrm{Tr}$ ) of precipitation in 13 cities

\begin{tabular}{|c|c|c|c|c|c|c|c|c|c|c|c|}
\hline \multirow{2}{*}{ No } & \multirow{2}{*}{ City } & \multicolumn{5}{|c|}{ Daily precipitation (mm/day) } & \multicolumn{5}{|c|}{ 3-day precipitation ( $\mathrm{mm} / 3$ days) } \\
\hline & & 1 & 2 & 5 & 10 & 25 & 1 & 2 & 5 & 10 & 25 \\
\hline 1 & Banjarmasin & 39 & 102 & 159 & 206 & 279 & 89 & 144 & 195 & 237 & 302 \\
\hline 2 & Banjarbaru & 36 & 127 & 172 & 198 & 227 & 105 & 165 & 204 & 232 & 269 \\
\hline 3 & Banjar & 49 & 114 & 132 & 144 & 158 & 82 & 114 & 132 & 144 & 158 \\
\hline 4 & Tanah Laut & 52 & 77 & 93 & 105 & 120 & 94 & 135 & 166 & 187 & 217 \\
\hline 5 & Barito Kuala & 57 & 66 & 85 & 105 & 139 & 97 & 119 & 140 & 157 & 180 \\
\hline 6 & Tapin & 46 & 81 & 118 & 149 & 202 & 85 & 135 & 173 & 201 & 241 \\
\hline 7 & HSS & 40 & 96 & 135 & 164 & 205 & 78 & 136 & 176 & 204 & 241 \\
\hline 8 & HST & 49 & 72 & 91 & 105 & 124 & 77 & 113 & 134 & 147 & 164 \\
\hline 9 & HSU & 37 & 93 & 129 & 154 & 186 & 58 & 143 & 175 & 191 & 207 \\
\hline 10 & Balangan & 42 & 71 & 96 & 116 & 145 & 57 & 112 & 143 & 163 & 188 \\
\hline 11 & Tabalong & 30 & 66 & 89 & 104 & 124 & 35 & 109 & 136 & 149 & 161 \\
\hline 12 & Tanah Bumbu & 21 & 70 & 94 & 108 & 123 & 46 & 119 & 148 & 163 & 179 \\
\hline 13 & Kotabaru & 23 & 69 & 84 & 91 & 97 & 59 & 115 & 146 & 165 & 189 \\
\hline
\end{tabular}

In general, discrepancies between the observed and predicted data are seen. It was expected due to several factors, namely differences in time zones, location of the data points, and adequacy of the observation data. TRMM was better at detecting rain events. However, in detecting heavy rainfall, GPM performed well by giving the best values for the $\mathrm{CC}$, FBS, POD, CSI, and HSS parameters and was used in the extreme value analysis.

The predicted monthly precipitation provided a better correlation value than the daily data. The CC data from ERA5, TRMM, and GPM were 0.803, 0.778, and 0.896 , respectively. Hence, GPM was also used in the anomaly analysis.

The GPM data were then corrected to resemble the observed data. A correction factor (C) was applied, which was determined based on Equation 3-6, in which $\mathrm{P}_{\mathrm{Oi}}$ and $\mathrm{P}_{\mathrm{Pi}}$ are the $\mathrm{i}^{\text {th }}$ observed and predicted precipitation, respectively. The graph between $\mathrm{C}$ and monthly precipitation is shown in Figure 3-5. The trend was divided into three regions, to each of which was applied a different correction factor, governed by the regression equation, except for values above $123 \mathrm{~mm}$. Statistically, the corrected data provided satisfactory agreement with the observed data, with a correlation of
0.896. The detailed statistics for the corrected GPM data are shown in Table 32.

$C=\frac{P_{O i}}{P_{P i}}$

\subsubsection{Extreme Precipitation Analysis}

In mapping flood hazards, it is important to consider extreme rain events. The World Meteorological Organization (2017) defines extreme precipitation as a value that exceeds the threshold set in a certain area and of a certain duration. In this study, the analysis aims to determine the extreme precipitation threshold for a certain return period $(\mathrm{Tr})$ of $1,2,5,10$, and 25 years for each of the 13 cities in South Kalimantan. The spatial averaged daily precipitation of the GPM data was used.

The extreme precipitation analysis was made by determining the data distribution using four methods, namely the normal method, normal log, and type I Gumbel. Furthermore, the Log Pearson Type III method was employed in cases of the analysis not meeting the requirements for the coefficients of skewness, kurtosis, and variation. Furthermore, the selected distribution was reviewed again using the Smirnov- 
Kolmogorov and Chi Square suitability test. The outputs of the extreme value analysis are shown in Table 3-3, given in daily and 3-day units (Gebremichael \& Hossain, 2010).

In the $\operatorname{Tr} 10$ of the daily data, the lowest extreme rainfall is found in Kotabaru, at $90.85 \mathrm{~mm} /$ day. There is no flooding event in Kotabaru during January 2021. Compared to the BMKG probabilistic standards, this value falls into the category of heavy rain (50-100 $\mathrm{mm} /$ day). BMKG defines extreme events as precipitation greater than 150 $\mathrm{mm} /$ day.

In general, the regions with the highest and lowest values at $\operatorname{Tr} 1$ year were Barito Kuala (57 mm/day) and Tanah Bumbu $(21 \mathrm{~mm} /$ day $)$. For 3-day precipitation, Banjarbaru had the highest level $(\operatorname{Tr} 1$ year $=105 \mathrm{~mm} / 3$ days $)$, while Banjarmasin had the potential to experience the most extreme 3-day precipitation $(\operatorname{Tr} 25$ years $=302 \mathrm{~mm} / 3$ days).

\subsubsection{Anomaly Analysis}

Anomaly analysis was conducted to characterize the yearly precipitation trends. This analysis referred to the method proposed by WMO to determine a climate normal, which is defined as the average of the climatological data calculated over a long and continuous duration, ideally 30 years (World Meteorological Organization, 2017). In this study, the sum parameter was analyzed to determine the annual precipitation anomaly based on the obtained climate normal.

Previous analysis shows that GPM was the closest to the behavior of the observed data. However, the GPM data only covers the period between June 2000 and February 2021, a duration which is not as ideal as the ERA5_Land data. However, in the WMO guidance, tolerance is given, namely for mean and sum analysis, so 12 years of data are still able to provide climate normal values close to ideal conditions; that is, a period of 30 years (World Meteorological Organization, 2017). Furthermore, spatially-averaged data were employed.

From the analysis, the climate normal (averaged yearly precipitation from 2001-2012) was 2,520.60 mm/year, only $5 \%$ lower than the climate normal of the ERA5_Land 30-year data. A graph of the GPM anomaly from 2001-2020 is shown in Figure 3-6, on which 2009 and 2010 were the years with the lowest $(2,013.3 \mathrm{~mm} /$ year $)$ and the highest values $(3,399.1 \mathrm{~mm} /$ year). It was also observed that the precipitation anomaly fluctuated around the average value. At the graph, the positive or negative anomalies are seen to be repeatedly occurred not more than two years consequently.

\section{DISCUSSION \\ 4.1 Flood Mechanism}

Table 4-1 presents the observation and GPM precipitation data at several locations in South Kalimantan in January 2021. At Banjarbaru station, 255.3 $\mathrm{mm} /$ day of precipitation was recorded on January 14, exceeding $\operatorname{Tr} 25$ years. Meanwhile, the Syamsuddin Noor, Bihara, and Sei Langkat stations experienced four days with precipitation exceeding $\operatorname{Tr} 2$ years.

In addition, the maximum daily and 3-day GPM precipitation during January 2021 was also analyzed. Daily data displayed a moderate range, with the highest value occurring at Barito Kuala Regency, at $68.3 \mathrm{~mm} /$ day $(\operatorname{Tr} 2.3)$. With regard to 3-day precipitation, the values in 12 cities were $\operatorname{Tr} 1-2$ years, while Banjar experienced a $\operatorname{Tr} 9$ year event $(141.5 \mathrm{~mm})$. The rainfall intensity explains the severe flooding that occurred. On the provincial scale, the series of rain events resulted in flooding in 11 cities. The direct impact was a 
massive runoff flowing into areas with dominantly low topography and gentle slopes. Indirectly, the amount of water accumulation also caused the collapse of part of the retaining wall at Takisung Pond in Tanah Laut, inundating the surrounding area up to a depth of 200 $\mathrm{cm}$.

At the same time, the tides acted as a secondary driver, occurring simultaneously with the extreme precipitation. The spring tide resulted in delays in freshwater flushing. Therefore, the flood remained longer on the mainland (Ajiwibowo \& Pratama, 2020). The predominantly diurnal type of tide, twelve hours after the high tide, will reach the peak ebb tide and provide a large flushing space. After January 15, the high and low tides continued to decline until reaching a neap tide on January 22.

Based on the Sentinel satellite imagery shown in Figure 2-4, the inundations were often found close to rivers; for instance, those in Banjarmasin, Banjar, Barito Kuala, and HSU. This is presumed to have been due to excessive river discharge and lower elevation, further intensified by the possibility of flow obstruction due to flood debris. Previous studies have shown that debris reduces river cross-sections and causes water to flow over banks (Wyżga, Kundzewicz, Ruiz- Villanueva, \& Zawiejska, 2016). The material is carried by the flow and achieves a great momentum, further resulting in a high hazard risk (Hajdukiewicz, Wyżga, Mikuś, Zawiejska, \& Radecki-Pawlik, 2016). As reported, two crucial bridges collapsed, the Pabahanan (Tanah Laut) and Mataraman (Banjar) (AntaraKalsel, 2021).

Future studies are recommended to scrutinize the flooding mechanism in more detail, reviewing its flood risk management using analytical calculations, numerical modelling, field surveys, analyze the community capacity index and resilience to flooding. Such studies are expected to identify factors whose significance is yet to be established (Borga, Anagnostou, Blöschl, \& Creutin, 2010). In this case, the effects of land-use change (plantation and mining) are certainly worthy of investigation. The existence of land subsidence in this area is yet to be ascertained but may further increase the flood severity (Pratama, 2019; Takagi, Esteban, \& Mikami, 2021)

\subsection{Precipitation Anomaly}

The compatibility test of the three predicted sets of data showed that GPM gave the smallest error. With regard to daily data, GPM data cannot mimic the exact trend of extreme precipitation (Table 3-2). However, in relation to monthly values, GPM provided a promising correlation value of 0.896 . The error of the GPM is due to the inaccuracy of satellites in pinpointing the monitoring stations.

The analysis of the GPM data from 2001-2020 indicated that the precipitation anomaly was influenced by global climate phenomena. Previous studies have underlined the significance of ENSO and IOD for the Indonesian climate (Hidayat \& Ando, 2018). ENSO, or the El Niño-Southern Oscillation and IOD, or the Indian Ocean Dipole, are defined as the interaction between the sea and the atmosphere in the Pacific and Indian Oceans.

ENSO consists of three conditions, namely El Niño, neutral, and La Niña. Meanwhile, IOD is categorized into positive, neutral, and negative IOD. The intensity of ENSO and IOD can be characterized based on the value of the ONI (Oceanic Niño Index) and DMI (Dipole Mode Index) (BOM, 2021; GGWS, 2021); the values are publicly available (JAMSTEC, 2021; Trenberth \& NCAR, 2020). 
Greater positive anomalies were obtained in 2010, 2016, and 2017, when La Niña or Negative IOD occurred. Meanwhile, in 2002, 2009, 2015, and 2018, El Niño, or positive IOD conditions, induced negative anomalies (Bramawanto $\&$ Sagala, 2016). The greatest anomalies in 2009 and 2010 coincided with a moderate El Niño and strong La Niña, respectively. Interestingly, with normal ENSO and IOD conditions, 2013 resulted in a significant positive anomaly.

Regarding the 2021 South Kalimantan flood, the ONI value for October, November and December was recorded at -1.3 (Medium La Niña). On the other hand, DMI for December and January were -0.17 and 0.21 (normal). These figures tend to indicate a positive precipitation anomaly. In December 2020 alone, ten rain events of $>100 \mathrm{~mm}$ were recorded (Banjarbaru, 2021).

Moreover, as shown in Table 41 ,observed total precipitation during the period 10-19 January was $672.8 \mathrm{~mm}$. This value is double the monthly (30 days) average January value from 2001 to 2020 using GPM data. Although this comparison is not necessarily equivalent due to data type (site-specific and regional data), it is mentioned to demonstrate the severity of the rainfall.

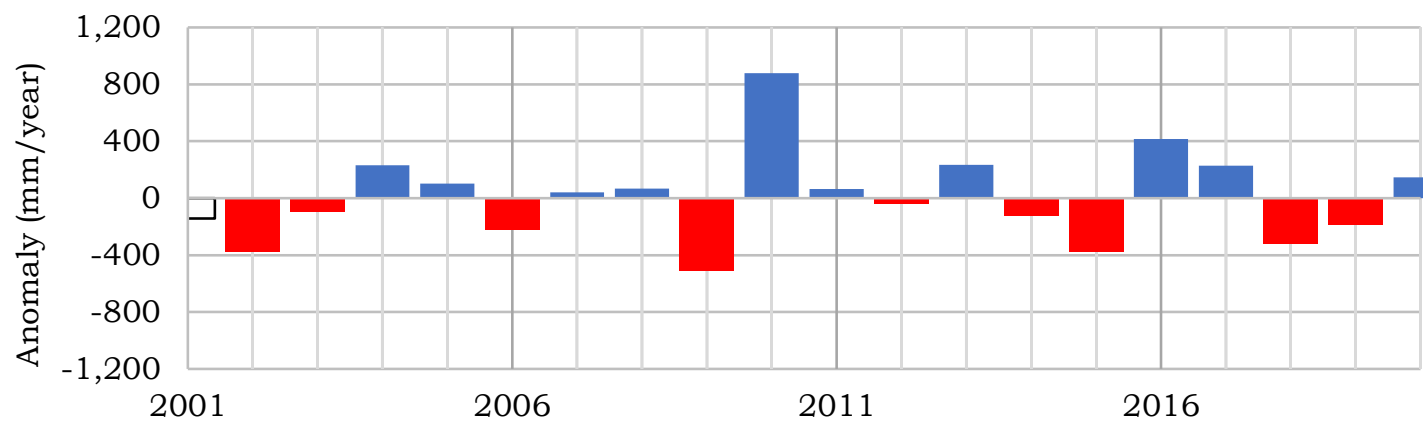

Figure 3-6 Precipitation anomalies at the highly inundated area from $2001-2020$

Table 4-1 Recorded and predicted precipitation at Banjarbaru, Balangan, and HSS

\begin{tabular}{|c|c|c|c|c|c|c|c|c|c|c|}
\hline \multirow{2}{*}{ Location } & \multicolumn{10}{|c|}{ Daily Precipitations (mm/day) } \\
\hline & 10 & 11 & 12 & 13 & 14 & 15 & 16 & 17 & 18 & 19 \\
\hline Banjarbaru & 104.0 & 61.9 & 21.6 & 15.9 & 255.3 & 97.3 & 72.6 & 0.0 & 21.9 & 22.3 \\
\hline S. Noor, Banjarbaru & 124.6 & 30.2 & $\mathrm{n} / \mathrm{a}$ & $\mathrm{n} / \mathrm{a}$ & $\mathrm{n} / \mathrm{a}$ & 131.0 & 58.1 & $\mathrm{n} / \mathrm{a}$ & $\mathrm{n} / \mathrm{a}$ & 11.0 \\
\hline GPM Banjarbaru & 17.9 & 35.6 & 15.9 & 70.7 & 49.2 & 26.3 & 1.2 & 13.2 & 5.3 & 0.8 \\
\hline Bihara, Balangan & 0.0 & 1.0 & 9.0 & 49.0 & 32.0 & $\mathrm{n} / \mathrm{a}$ & $\mathrm{n} / \mathrm{a}$ & $\mathrm{n} / \mathrm{a}$ & $\mathrm{n} / \mathrm{a}$ & $\mathrm{n} / \mathrm{a}$ \\
\hline GPM Balangan & 3.1 & 1.9 & 1.5 & 37.7 & 15.5 & 21.8 & 3.7 & 2.7 & 11.4 & 0.3 \\
\hline Sei Langsat, HSS & 116.0 & 75.0 & 51.0 & 157.0 & 36.0 & $\mathrm{n} / \mathrm{a}$ & $\mathrm{n} / \mathrm{a}$ & $\mathrm{n} / \mathrm{a}$ & $\mathrm{n} / \mathrm{a}$ & $\mathrm{n} / \mathrm{a}$ \\
\hline GPM HSS & 25.3 & 0.9 & 0.0 & 53.0 & 13.0 & 33.9 & 1.4 & 1.1 & 18.9 & 3.0 \\
\hline
\end{tabular}

$\mathrm{n} / \mathrm{a} \quad$ : not available

\section{CONCLUSION}

This study has presented a description and chronology, as well as topographical, tidal, and precipitation analysis related to the 2021 South Kalimantan flood. The precipitation reached $\operatorname{Tr} 2$ and 25 and lasted for 10 days. Total precipitation was 672.8 $\mathrm{mm} / 10$ days, with the rain occurring simultaneously with the spring tide, resulting in massive water accumulation in the low and sloping topography. Inundation was evident downstream and along the Riam Kanan River in Banjarmasin, the Martapura River in Banjar and Banjarbaru, and Amuntai District in HSU (150 km from the coast).

Furthermore, the GPM data are reliable in predicting monthly precipitation. Analysis using 20 years of 
data indicated a correlation between precipitation and ENSO-IOD. La Niña and neutral IOD at the end of 2020 could be an early warning for further extreme rain events in 2021. To increase local awareness and regional resilience to flood, installation of flood early warning system and educating the residents due to mitigation itself is required.

In a number of communities, it is suspected that land use, particularly palm plantations, coal mining and any other illegal mining waste disposal system into the river, contributed significantly to the disaster, although this is beyond the scope of this study. Therefore, further studies are suggested to investigate the interaction between various aspects, such as hydrology, meteorology, climatology, oceanography, and land-use changes. The significance of each aspect is still open to question and essential in determining disaster risk and designing flood resilience in South Kalimantan.

\section{ACKNOWLEDGEMENTS}

Authors are grateful to the Indonesian and international agencies who made the data used in this research publicly available; in Indonesia BWS Kalimantan III, BMKG, BIG, BNPB, BPBD, BPS, and Hengki Purwonegoro, and internationally, CDS, GSFC-NASA, IHO, and Sentinel. The authors would also like to express gratitude to the journal's editorial team and reviewer for their valuable comments.

\section{AUTHORS CONTRIBUTION}

Conceptualizaion - MBP; Methodology MBP, RMW, INA; Data preparation - MBP, RMW; Visualization - INA; Analysis MBP, RMW, INA; Writing - MBP; Review and Editing - RMW, INA.

\section{REFERENCES}

Acker, J.G., \& Leptoukh G. (2007). Online Analysis Enhances Use of NASA Earth
Science Data. Eos 88(2),14-17. https: / /doi.org/10.1029/2007EO020003

Ajiwibowo, H., \& Pratama, M.B. (2020). Hydrodynamic Changes Impacted by the Waterway Capital Dredging in Cikarang Bekasi Laut Channel, West Java, Indonesia. Water Practice and Technology 15(2), 450-459. https://doi.org/10.2166/wpt.2020.032

AntaraKalsel (2021). Severe Flooding Submerges Most of S Kalimantan, Road Cut off. Available via ANTARA News Kalimantan Selatan. Retrieved January 15, 2021, from https://kalsel.antaranews.com/berita/2 27572 /severe-flooding- submerges-mostof-s-kalimantan- road-cut-off

Balai Hidrologi dan Lingkungan Keairan (2021). Laporan Analisis Bencana Banjir, Kabupaten Banjar, Kabupaten Tanah Laut, Kabupaten Balangan, Dan Kota Banjarmasin [Flood Disaster Analysis Report, Banjar Regency, Tanah Laut Regency, Balangan Regency, and Banjarmasin City], Bandung.

BIG (2021a). DEMNAS. Retrieved January 21, 2021 , from http://tides.big.go.id/DEMNAS/index.ht $\mathrm{ml}$

BIG (2021b). Online Tide Prediction/Prediksi Pasang Surut (Pasut) Retrieved January 21, 2021, from http://tides.big.go.id/pasut

BIG (2021c). Realtime Tidal Observation/Pengamatan Pasang Surut Realtime. Retrieved January 21, 2021, from

http:/ / tides.big.go.id:8888/dash/pro

$\mathrm{v} /$ Kalsel.html

BMKG. (2021a). Data Online - Pusat DatabaseBMKG. Available via BMKG. Retrieved January 25, 2021, from https://dataonline.bmkg.go.id/home

BMKG (2021b). Probabilistik Curah Hujan 20 Mm (Tiap 24 Jam). Retrieved January 26, 2021, from Available via BMKG. https://www.bmkg.go.id/cuaca/prob abilistik-curah-hujan.bmkg

BNPB (2021a). Update - 10 Kabupaten/Kota 
Terdampak Banjir Di Kalimantan Selatan. Retrieved January 26, 2021, from https://bnpb.go.id/berita/-update- 10kabupaten-kota-terdampak- banjir-dikalimantan-selatan

BNPB (2021b). Ribuan Rumah Warga Sejumlah Kabupaten Di Kalimantan Selatan Dilanda Banjir. Retrieved January 26, 2021, from https://bnpb.go.id/berita/Ribuan Rumah Warga Sejumlah Kabupaten di Kalimantan Selatan Dilanda Banjir

BOM (2021). About ENSO and IOD Graphs. Retrieved January 28, 2021, from http://www.bom.gov.au/climate/ens $\mathrm{o} /$ indices/about.shtml

Borga, M., Anagnostou, E.N., Blöschl, G., \& Creutin, J.D. (2010). Flash Floods: Observations and Analysis of HydroMeteorological Controls. Journal of Hydrology 394(1-2), 55-59

https://doi.org/10.1016/j.jhydrol.20 10.07 .048

BBPS Kalimantan Selatan (2021). Badan Pusat Statistik Provinsi Kalimantan Selatan.

Bramawanto, R., \& Sagala, S.L. (2016). Meteorological and Physical Conditions of Salt Pan Areas with Filtering-Threaded Technology (TUF) in Cirebon Regency, Indonesia. Jurnal Segara 12(2), 81-90. https://doi.org/10.15578/segarav1 $2 \mathrm{i} 2.7678$

Copernicus Sentinel (2021). Copernicus Open Access Hub. Retrieved January 29, 2021, from

https://scihub.copernicus.eu/dhus/ \#/home.

Deltares. (2021). Tide Stations - Delft Dashboard - Deltares Public Wiki. Retrieved January 29, 2021, from https: / / publicwiki.deltares.nl/displa $\mathrm{y} / \mathrm{DDB} /$ Tide+Stations.

Dwirahmadi, F., Rutherford, S., Phung, D., \& Chu, D., (2019). Understanding the Operational Concept of a Flood-Resilient Urban Community in Jakarta, Indonesia, from the Perspectives of Disaster Risk Reduction, Climate Change Adaptation and Development Agencies. International
Journal of Environmental Research and Public Health 16(20), 3993. https://doi.org/10.3390/ijerph16203993 Fatkhuroyan (2019). Perbandingan Sebaran Curah Hujan Hasil Observasi Satelit GPM Dengan Model Cuaca WRF Studi Kasus: Siklon Tropis Cempaka Dan Dahlia 27 Nov - 3 Des 2017. Paper presented at Penggunaan Dan Pengembangan Produk Informasi Geospasial Mendukung Daya Saing Nasional, Seminar Nasional Geomatika, 2018.

GGWS (2021). El Nino and La Nina Years and Intensities. Available via GG Weather. Retrieved January 30, 2021, from https://ggweather.com/enso/oni.htm

Geoportal Kalsel, (2021), Geoservis Kalsel. Retrieved January 30, 2021, from http://geoservice.kalselprov.go.id

Hajdukiewicz, H., Wyżga, B., Mikuś, P., Zawiejska, J., \& Radecki-Pawlik, A. (2016). Impact of a Large Flood on Mountain River Habitats, Channel Morphology, and Valley Infrastructure. Geomorphology 272, 55-67. https://doi.org/10.1016/j.geomorph. 2015.09.003

Harvey, L.O., Hammond, K.R., \& Lusk, C.M. (1992), The Application of Signal Detection Theory to Weather Forecasting Behavior. Monthly Weather Review 120(5), 863-83. https://doi.org/10.1175/15200493

Hidayat, R., \& Kentaro, A. (2018). Variabilitas Curah Hujan Indonesia Dan Hubungannya Dengan ENSO/IOD Estimasi Menggunakan Data JRA25/JCDAS. Agromet 28(1), 1-8. https://doi.org/10.29244/j.agromet.28.1 .1-8.

Hurford, A., Maksimovic, C., \& Leitao, J.P. (2010). Urban Pluvial Flooding in Jakarta: Applying State-of-the-art Technology in a Data Scarce Environment. Water Science \& Technology 62(10), 2246-2255. https://doi.org/10.2166/wst.2010.485

JAMSTEC (2021). JAMSTEC Visualization. Retrieved January 30, 2021, from 
http://www.jamstec.go.jp/virtualeart

$\mathrm{h} /$ general/en/index.html.

JICA (2010). The Study On Guidelines For Assessing Port Development Priorities Including Acceptable Performance Levels In ASEAN. Tokyo: Mitsubishi Research Institute, Inc

KITLV(1928). Overstroomde Straten Te Barabai. Retrieved January 30, 2021, from http:/ / hdl.handle.net/1887.1/item:7 74858 .

Ko, D.H., Jeong, S.T., \& Cho, H.Y. (2018). Analysis on the Estimation Errors of the Lowest and Highest Astronomical Tides for the Southwestern 2.5 GW Offshore Wind Farm, Korea. International Journal of Naval Architecture and Ocean Engineering $10(1)$, 85-94.

https://doi.org/10.1016/j.ijnaoe.201

7.03 .004

Latief, H., Putri, M., \& Hanifah, F.N. (2018). Coastal Hazard Assessment in Northern part of Jakarta. Procedia Engineering 212,1279-1286.

https://doi.org/10.1016/j.proeng.2018.0 1.165

Manalu, A. (2021). Mengkaji Penyebab Banjir Kalsel. Kalimantan Selatan

NCAR (2017). GPM: Global Precipitation Measurement Mission. Retrieved January 30, 2021, from https:/ / climatedataguide.ucar.edu/clima te-data/gpm-global- precipitationmeasurement-mission.

Nurtyawan, R., \& Fiscarina, N. (2020). Assessment of the Accuracy of Dem From Panchromatic Pleiades Imagery Case Study: Bandung City. West Java. International Journal of Remote Sensing and Earth Sciences (IJReSES) 17(1), 35-44. https://doi.org/10.30536/j.ijreses.2020. v17a3329

Purwonegoro, H. (2021). Flood Mapping South Kalimantan [Image]. Retrieved January 31, 2021, from https://www.linkedin.com/ posts/hengki

purwonegoro18242250_flood- mapping- south-kalimantan-activity-

6762294784892788736-wzQK.

Pratama, M.B. (2019). Tidal Flood in Pekalongan: Utilizing and Operating Open Resources for Modelling. IOP Conf.Ser.: Mat. Sci. Eng, 676 ,

1-10.

https://doi.org/10.1088/1757-

899X/676/1/012029

Putra, H.E., Putro, D.A., \& Hadi, T.W. (2016), High Resolution Flood Hazard Mapping Using Two-Dimensional Hydrodynamic Model ANUGA: Case Study of Jakarta, Indonesia. The 18th International Conference on Flood Recovery, Innovation and Response, Paris, France, October 2425, 2016. Paris: FMA.

Supari \& Setiawan, N. (2013). Rainfall Variability Over Bangka Belitung Island Based On Validated TRMM Product. Jurnal Meteorologi Dan Geofisika, 14(1), 9-17. https://doi.org/10.31172/jmg.v14i1.140

Takagi, H., Esteban, M., Mikami, T., \& Fujii, D. (2016). Projection of Coastal Floods in 2050 Jakarta. Urban Climate 17, 135-145. https://doi.org/10.1016/j.uclim.2016.05 .003

Takagi, H., Esteban, M., Mikami, T., Pratama, M., Valenzuela, V., \& Avelino, J. (2021). People's Perception of Land Subsidence, Floods, and Their Connection: A Note based on Recent Surveys in a Sinking Coastal Community in Jakarta. Ocean \& Coastal Management 211, 105753. https://doi.org/10.1016/j.ocecoaman.20 21.105753

Tarek, M., Brissette, F.P., \& Arsenault, R. (2020). Evaluation of the ERA5 Reanalysis as a Potential Reference Dataset for Hydrological Modelling over North America. Hydrology and Earth System Sciences 24(5), 2527-2544. https://doi.org/10.5194/hess-24-2527-2020

Tirto (2021, January 31). Penyebab Banjir Kalsel Menurut Analisis LAPAN, Aktivis, Dan KLHK. Tirto. Retrieved from https://tirto.id/penyebab-banjir- kalselmenurut-analisis-lapan- aktivis-dan- 
klhk-f9uk.

Trenberth, K., \& NCAR. (2020). The Climate Data Guide: Nino SST Indices Nino 1+2, 3, 3.4, 4; ONI and TNI.

World Meteorological Organization. (2017). Guidelines on the Calculation of Climate Normals (2017 eds). Geneva: WMO.
Wyżga, B., Kundzewicz, Z.W., Ruiz- Villanueva, V., \& Zawiejska, J. (2016). Flood Generation Mechanisms and Changes in Principal Drivers. GeoPlanet: Earth and Planetary Sciences, 0, 55-75. https://doi.org/10.1007/978-3-3194192 